\title{
Multifractal analysis of soil penetration resistance under sugarcane cultivation
}

\author{
Jairo O. R. Leiva ${ }^{1}$, Raimunda A. Silva ${ }^{1}$, Ricardo N. Buss² ${ }^{2}$, Victor L. França ${ }^{1}$, \\ Anderson A. Souza ${ }^{1} \&$ Glécio M. Siqueira ${ }^{1}$
}

\begin{abstract}
${ }^{1}$ Universidade Federal do Maranhão/Departamento de Geociências, São Luís. MA, Brasil. E-mail: leivaagro@gmail.com - ORCID: 0000-0002-1803-2241; ray-234@hotmail.com - ORCID: 0000-0002-0380-8190; vlamarao@gmail.com - ORCID: 0000-0002-9527-3030; anderson.souzza@outlook.com - ORCID: 0000-0002-6890-0975; gleciosiqueira@hotmail.com (Correspondig author) - ORCID: 0000-0002-3513-2658

${ }^{2}$ Universidade Federal de Santa Catarina/Departamento de Ciência da Administração, Florianópolis, SC, Brasil. E-mail: rnbuss@gmail.com - ORCID: 0000-0003-3444-4243
\end{abstract}

\begin{abstract}
Soil resistance to penetration (PR) is an indirect measure of the state of soil compaction. Thus, the objective of this study was to characterize PR in vertical profiles in an area cultivated with sugarcane using multifractal models for different relief units. The experiment was carried out in an Oxisol with a clay texture, with 6.85 ha in the municipality of Coelho Neto (Maranhão state, Brazil), where 60 sampling points were demarcated. The area was divided into four relief units (Type A $>74 \mathrm{~m}$, Type B from 71 to $74 \mathrm{~m}$, Type C from 68 to $71 \mathrm{~m}$ and Type D from 65 to $68 \mathrm{~m}$ ). The PR was measured at the 60 sampling points using an impact penetrometer, and the PR determined in the 0-0.60 m depth layer every $0.01 \mathrm{~m}$. The multifractal analysis was performed considering the scale property of each profile and typified the singularity and Rènyi spectra estimated using the current method. Multifractal analysis allowed the identification of patterns at different scales and with high heterogeneity. The multifractal behavior was represented by the singularity spectrum $(\alpha)$, versus $f(\alpha)$, and the generalized dimension (Dq). The multifractal analysis allowed the differentiation between the profiles of the relief units (Types A, B, C and D), resulting in an important tool for studies of soil resistance to penetration.
\end{abstract}

Key words: fractal geometry, fractal dimension, singularity spectrum, geostatistics, soil management

\section{Análise multifractal da resistência do solo à penetração sob cultivo de cana-de-açúcar}

RESUMO: A resistência do solo à penetração (RP) é uma medida indireta do estado de compactação do solo. Assim, o objetivo deste trabalho foi caracterizar a RP em perfis verticais em uma área cultivada com canade-açúcar por meio de modelos multifractais para diferentes unidades de relevo. O experimento foi realizado em Latossolo Vermelho Amarelo textura argilosa, com 6.85 ha no município de Coelho Neto (Maranhão, Brasil), onde foram demarcados 60 pontos de amostragem. A área foi dividida em quatro unidades de relevo (Tipo A > 74 m; Tipo B de 71 a 74 m; Tipo C de 68 a $71 \mathrm{~m}$ e Tipo D de 65 a $68 \mathrm{~m}$ ). A RP foi medida nos 60 pontos de amostragem utilizando um penetrômetro de impacto, e a RP determinada na camada de $0-0.60 \mathrm{~m}$ de profundidade a cada $0.01 \mathrm{~m}$. A análise multifractal foi realizada considerando a propriedade de escala de cada perfil e tipificada o espectro de singularidade e de Rènyi estimados por meio do método do momento. A análise multifractal permitiu a identificação de padrões em diferentes escalas e com elevada heterogeneidade. O comportamento multifractal, foi representado pelo espectro de singularidade $(\alpha)$, versus $f(\alpha)$, e a dimensão generalizada (Dq). A análise multifractal permitiu a diferenciação entre os perfis das unidades de relevo (Tipos A, B, C e D), resultando em uma importante ferramenta para estudos da resistência do solo à penetração.

Palavras-chave: geometria fractal, dimensão fractal, espectro de singularidade, geoestatística, manejo de solo 


\section{INTRODUCTION}

Fractal and multifractal models can be used to elucidate the complexity of processes that determine soil characteristics (Halsey et al., 1986; Caniego et al., 2006). According to Evertsz \& Mandelbrot (1992), a monofractal system is characterized by a simple scale, while a multifractal system involves a continuous spectrum of scale exponents which are related to complex processes at different levels of intensity. According to Banerjee et al. (2011), a multifractal analysis can reveal more information about data heterogeneity than other spatial techniques.

In this sense, research on soil compaction should consider mathematical models that take soil heterogeneity into account, even at small scales. The degree of compaction of soil can be characterized by measuring its resistance to penetration based on its dynamic nature and its interaction with other factors such as soil composition, structure, bulk density, porosity and water content (Lipiec \& Hatano, 2003; Siqueira et al., 2015; Lima et al., 2017; Tavares et al., 2017). Folorunso et al. (1994) examined the soil penetration resistance (PR) in parallel transects and found that fractal analysis allowed a qualitative discrimination of soils, despite small variations across scales. Roisin (2007) found that soil management affected PR multifractality. Siqueira et al. (2013) used multifractal and geostatistic techniques to study vertical profiles of PR and concluded that $\mathrm{PR}$ is variable on a vertical and horizontal scale. Studying the effects of soil bulk density and water potential on PR multifractality, Paz-Ferreiro et al. (2013) found that increasing bulk density caused a decrease in PR multifractality. Wilson et al. (2016) used multifractal analysis techniques to study PR due to the increase of water deficit and observed that $P R$ values become increasingly heterogeneous with decreasing soil water content.

Thus, the aims of this study were a) to analyze the vertical PR profiles under sugarcane cultivation by means of multifractal techniques, b) to test whether the multifractality of vertical PR profiles was influenced by the relief, and c) to characterize the spatial variability of PR and multifractal parameters.

\section{Material ANd Methods}

The study area was conducted at the Itajubara Mill in the municipality of Coelho Neto, state of Maranhão, Brazil ( $4^{\circ} 19^{\prime}$ $5^{\prime \prime} \mathrm{S}, 43^{\circ} 0$ ' 22" W, at an altitude of $71 \mathrm{~m}$ ). The experimental area covered 6.85 ha and had been cultivated with sugarcane (Saccharum officinarum), variety RB92579, since 2014. The soil of the area was classified as an Oxisol.

In total, 60 sampling points were randomly selected to determine soil penetration resistance $(\mathrm{PR})(\mathrm{MPa})$, and they were classified into four relief units (Figure 1): type A, > 74 m; type $\mathrm{B}$, from 71 to $74 \mathrm{~m}$; type $\mathrm{C}$, from 68 to $71 \mathrm{~m}$; and type $\mathrm{D}$, from 65 to $68 \mathrm{~m}$.

Soil PR was measured using an impact penetrometer with a 0.0125-m diameter steel cone, at a $30^{\circ}$ angle. PR measurements were performed on April 22, 2016 with soil at field capacity $\left(\theta=0.14 \mathrm{~m}^{3} \mathrm{~m}^{-3}\right)$, which was determined in the laboratory by placing the samples in soil retaining rings in a Richards

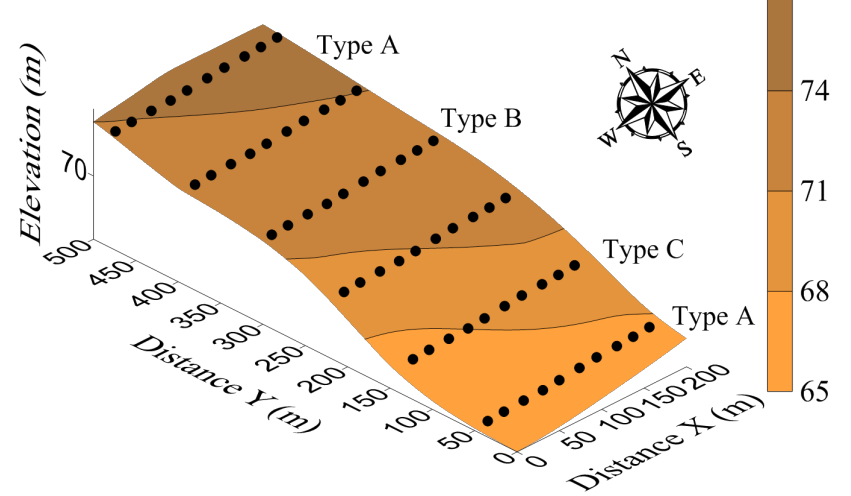

Figure 1. Topographic map and sampling scheme of 60 sampling points and relief units (types A, B, C and D)

pressure plate device. The PR values were determined in the $0-0.60 \mathrm{~m}$ depth layer at $0.01 \mathrm{~m}$ intervals, and 60 vertical $P R$ profiles were generated.

Descriptive statistics were obtained using $\mathrm{R}$ software version 3.3.1 (R Development Core Team, 2017). The multifractal analysis was performed using the method of moments to obtain multiple PR scales, considering a one-dimensional profile of length $\mathrm{L}$, this involves successive partitioning into $\mathrm{k}$ stages $(\mathrm{k}=1,2,3 \ldots)$, and successive partitioning was produced at each scale $\delta$, a number of segments $\mathrm{N}(\delta)=2^{\mathrm{k}}$ are obtained with a characteristic size length, $\delta=\mathrm{L} \times 2^{\mathrm{k}}$, covering the whole extent of the support L (Evertsz \& Mandelbrot, 1992; Caniego et al., 2006; Vidal-Vázquez et al., 2013).

The expression of the data as a function of mass $p_{i}(\delta)$, at time resolution $\delta$ was estimated according to Eq. 1 and the size of the segments was calculated using Eq. 2:

$$
\begin{gathered}
\mathrm{p}_{\mathrm{i}}(\delta)=\frac{\mathrm{N}_{\mathrm{i}}(\delta)}{\mathrm{N}_{\mathrm{t}}} \\
\chi(\mathrm{q}, \delta)=\sum_{\mathrm{i}=1}^{\mathrm{N}(\delta)} \mathrm{p}_{\mathrm{i}}^{\mathrm{q}}
\end{gathered}
$$

where

$\mathrm{p}_{\mathrm{i}}(\delta)$ - probability mass distribution;

$\mathrm{N}_{\mathrm{i}}(\delta)$ - value of the measure in a given segment I;

$\mathrm{N}_{\mathrm{t}}$ - sum of the measure in the whole transect;

$\mathrm{N}(\delta)$ - number of segments with size $\delta$. The statistical moment $\mathrm{q}$ is defined as $-\infty<\mathrm{q}<\infty$; and,

$\chi(q, \delta)$ - scale of partition function, in the moments $(q)$ and generated segments of order $(\delta)$.

To estimate the exponent of mass function, $\tau$, with the mass scaling function of order q, using Eq. 3, and the distribution probability was given as $\mathrm{p}_{\mathrm{i}}(\delta)=\delta^{\mathrm{ai}}$, where $\alpha_{\mathrm{i}}$ is the singularity or Hölder exponent characterizing density in the $\mathrm{i}^{\text {th }}$ box (Halsey et al., 1986). The Hölder exponent was calculated as $\alpha_{i}=\log \mu_{i}(\delta) / \log \delta$, which can be used to evaluate the degree of concentration of the measure $\mu$.

$$
\tau(\mathrm{q})=\lim _{\delta \rightarrow 0} \frac{\log \chi(\mathrm{q}, \delta)}{\log \left(\frac{1}{\delta}\right)}
$$


where

$\tau(\mathrm{q})$ - mass exponent function;

$\mu_{i} \quad$ - region of concentration of a measure in the Hölder exponent; and,

$\delta \quad$ - generated segment length.

The relation between the exponent $\tau_{q}$ and $f(\alpha)$ can be obtained using the Legendre transformation. However, the Legendre transformation is unsatisfactory in some situations, mainly due to errors in the estimation of $f(\alpha)$. Thus, in the present study, $\tau_{q}$ and $f(\alpha)$ were estimated using the direct method of Chhabra \& Jensen (1989) using Eqs. 4 and 5.

$$
\begin{gathered}
\alpha(\mathrm{q}) \propto \frac{\sum_{\mathrm{i}=1}^{\mathrm{N}(\delta)} \mu_{\mathrm{i}}(\mathrm{q}, \delta) \log \left[\mu_{\mathrm{i}}(\delta)\right]}{\log (\delta)} \\
\mathrm{f}(\alpha(\mathrm{q})) \propto \frac{\sum_{\mathrm{i}=1}^{\mathrm{N}(\delta)} \mu_{\mathrm{i}}(\mathrm{q}, \delta) \log \left[\mu_{\mathrm{i}}(\mathrm{q}, \delta)\right]}{\log (\delta)}
\end{gathered}
$$

where

$\propto \quad$ - is proportional to.

The generalized dimension was defined according to Eq. 6 , where $\mathrm{D}_{1}$ is indeterminate because the denominator value is zero. Therefore, for the particular case in which $\mathrm{q}=1$ was used, according to Eq. 7, considering a stationary stochastic process defined by $\chi=\left(\chi_{i}: i=0,1,2, \ldots\right)$, with constant mean $\mu$ and finite variance $\alpha^{2}$.

$$
\begin{gathered}
\mathrm{D}_{\mathrm{q}}=\frac{\tau(\mathrm{q})}{(\mathrm{q}-1)} \\
\mathrm{D}_{1}=\lim _{\delta \rightarrow 0} \frac{\sum_{\mathrm{i}=1}^{\mathrm{N}(\delta)} \chi_{\mathrm{i}}(1, \delta) \log \left[\mu_{\mathrm{i}}(1, \delta)\right]}{\log \delta}
\end{gathered}
$$

In a monofractal, $\mathrm{D}_{\mathrm{q}}$ is a constant function of $\mathrm{q}$, and in multifractals, the relationship between $\mathrm{D}_{\mathrm{q}}$ and $\mathrm{q}$ is not constant. The Hurst exponent $(\mathrm{H})$ was determined using the expression $\mathrm{D}_{2}=2 \mathrm{H}-1$.

Geostatistical analyses were performed considering the intrinsic hypothesis and after adjustment of the semivariograms, obtaining the following parameters: $\mathrm{C}_{0}$ (nugget effect), $\mathrm{C}_{0}+\mathrm{C}_{1}$ (sill) and a (range, $\mathrm{m}$ ). The software Surfer 11 (Golden Software, 2014) was used to construct the isoline maps of soil PR and multifractal parameters.

\section{Results AND Discussion}

The vertical PR profiles of different relief units are shown in Figure 2 (A, B, C and D): type A (profiles 2, 7, 10 and 21), type B (profiles 11, 13, 16 and 26), type $C$ (profiles 18, 22, 25 and 27), and type D (profiles 28, 41, 47 and 60). The PR patterns of type A, B and C relief units was similar and showed
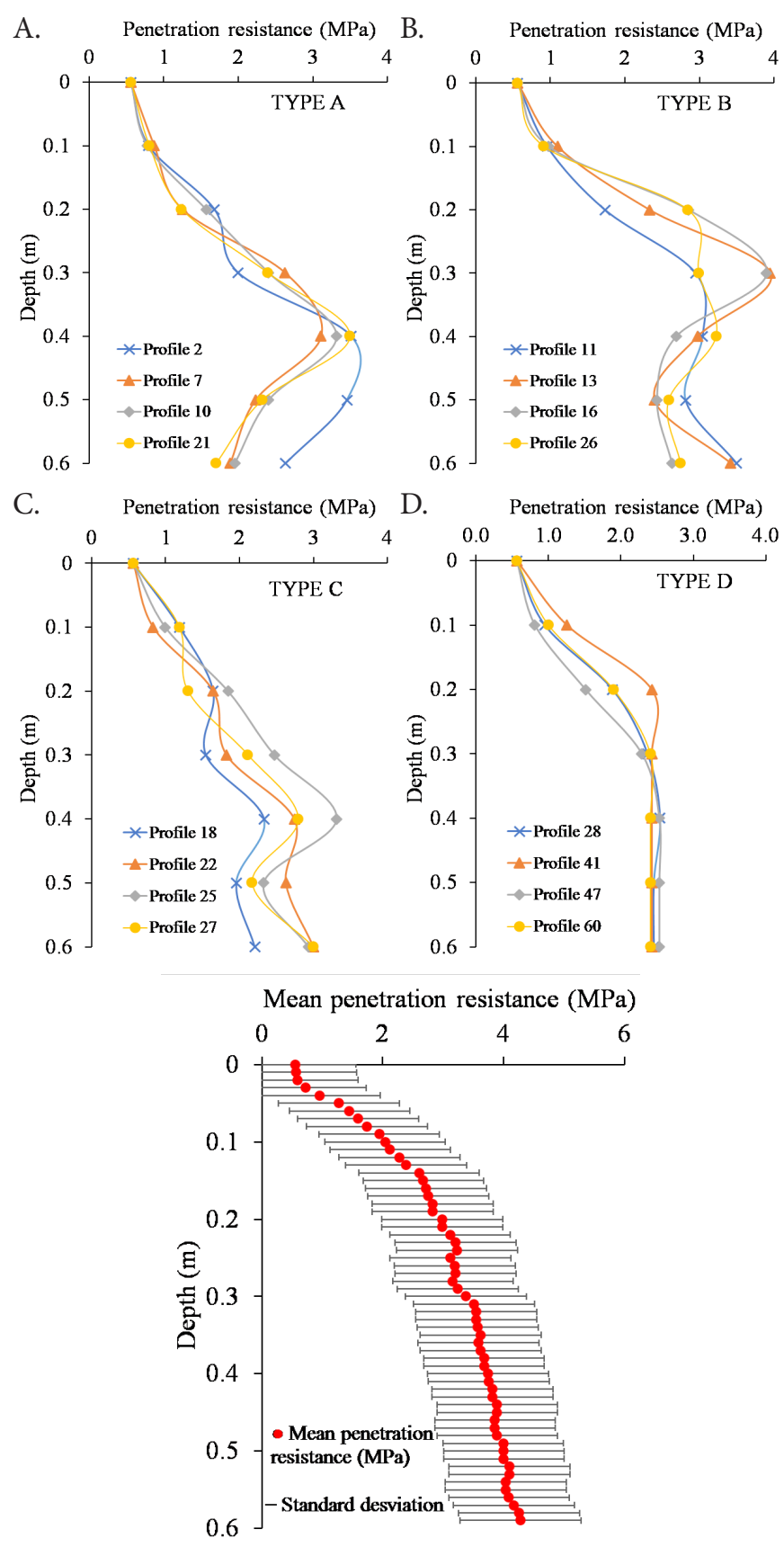

Figure 2. Vertical profiles of PR in the $0-0.60 \mathrm{~m}$ depth layer for the different relief units (types A, B, C and D) and mean and standard deviation of the 60 vertical PR profiles (E) under sugarcane cultivation

increasing PR to depths of $0.3 \mathrm{~m}$ (type $\mathrm{B}$ ) and $0.4 \mathrm{~m}$ (Types A and C) and then decreasing PR to a depth of $0.6 \mathrm{~m}$. Lima et al. (2017) and Tavares et al. (2017) suggested that PR is influenced by soil clay content and bulk density, which is associated with the volumetric content of water. Therefore, the greater PR homogeneity over depth in the type D relief unit is likely associated with the dynamics of water in soil since this relief unit had the lowest elevation (between 65 and $68 \mathrm{~m}$ ).

The mean and standard deviation of PR in the vertical profiles of the 0-0.60 m layer are shown in Figure 2E. The increase in standard deviation with depth is because soil management under sugarcane cultivation typically results in homogenization of the surface layer, as reported by Tavares et al. (2017). The plot shows that the lowest PR 
value was $0.594 \mathrm{MPa}$, and the highest value was $4.277 \mathrm{MPa}$. Several studies reported that PR values above $2 \mathrm{MPa}$ limit the development of sugarcane crop (Otto et al., 2011; Sá et al., 2016), and other studies suggested different threshold values to limit the development of most crops, e.g. 2.5 MPa (Gonçalves et al., 2014), 3.0 MPa (Souza et al., 2015), or ranging from 2.8 to $3.2 \mathrm{MPa}$ (Vepraskas \& Miner, 1986).

The lowest mean PR occurred in profile $18(1.79 \mathrm{MPa})$ and the maximum value was observed in profile $13(2.67 \mathrm{MPa})$ in types C and B relief units, respectively. Sá et al. (2016) studied soil PR limiting the development of sugarcane and reported values of 3.8 $\mathrm{MPa}$ as limiting for crop growth; in the present study, however, the PR values in the representative profiles of each relief unit (Table 1; Figure 2) were below 3.8 MPa. Lipiec \& Hatano (2003) suggested that PR values above $4 \mathrm{MPa}$ prevented root development in sugarcane. However, Siqueira et al. (2013) found that under favorable moisture conditions in the field, root development was not compromised, even at high $\mathrm{PR}$ values.

Skewness, kurtosis and maximum deviation indicated normal frequency distributions in eight profiles (profiles
$2,7,10,13,16,22,25$ and 27) and log-normal frequency distributions in eight profiles (profiles 21, 11, 26, 18, 28, 41, 47, and 60). Siqueira et al. (2013) and Tavares et al. (2017) suggested that a high variation in PR data is due to the high variability of PR values throughout the landscape.

The partition functions were constructed for successive segments of different sizes, i.e., $2^{\mathrm{k}}$, with $\mathrm{k}=0$ to $\mathrm{k}=5$, and moments in the interval $\mathrm{q}=+5$ to $\mathrm{q}=-5$. The partition functions of the profiles 22 (type C) and 60 (type D) and the graphs that presented the best and worst coefficient of determination $\left(\mathrm{R}^{2}\right)$ which was $\mathrm{R}^{2}=0.99993$ and $\mathrm{R}^{2}=0.99615$, respectively are shown in Figure 3 (A and B). According to Siqueira et al. (2018), $\mathrm{R}^{2}$ above 0.9 indicates strong scales for the moments of order $\mathrm{q}[-5,5]$. Thus, the data followed a power law characterizing multifractal scales, as described by Banerjee et al. (2011). Vidal-Vázquez et al. (2013) reported that the presence of multiple scales indicates a multifractal, whereas single scales characterize a monofractal.

The multifractal dimensions for PR in the dimensions $\left(\mathrm{D}_{-5}-\mathrm{D}_{5}, \mathrm{D}_{-5}, \mathrm{D}_{5}, \mathrm{D}_{0}, \mathrm{D}_{1}\right.$ and $\left.\mathrm{D}_{2}\right)$ is presented in Table 2. The

Table 1. Descriptive statistics of the representative profiles of soil penetration resistance (PR) in the four relief units

\begin{tabular}{|c|c|c|c|c|c|c|c|c|c|c|c|c|c|c|c|c|}
\hline & \multicolumn{4}{|c|}{ Type A (Profile) } & \multicolumn{4}{|c|}{ Type B (Profile) } & \multicolumn{4}{|c|}{ Type C (Profile) } & \multicolumn{4}{|c|}{ Type D (Profile) } \\
\hline & 2 & 7 & 10 & 21 & 11 & 13 & 16 & 26 & 18 & 22 & 25 & 27 & 28 & 41 & 47 & 60 \\
\hline Mea & 2.39 & 1.98 & 2.05 & 1.92 & 2.46 & 2.67 & 2.37 & 2.52 & 1.79 & 1.93 & 2.28 & 1.83 & 2.03 & 1.94 & 2.00 & 1.94 \\
\hline SD & 1.07 & 0.89 & & 0.74 & 0.98 & 1.12 & 1.24 & & 0.51 & 0.75 & 0.86 & 0.79 & 0.65 & 0.46 & 0.75 & 0.46 \\
\hline CV & 44.90 & 5.13 & 44.12 & 38.60 & 39.72 & 42.00 & 52.57 & 38.68 & 28.66 & 39.15 & 37.76 & 43.31 & 32.16 & 23.90 & 37.39 & 23.90 \\
\hline Ske & 0.38 & 0.27 & 0.24 & -0.33 & -0.46 & 0.10 & 0.44 & -0.34 & -0.51 & -0.09 & -0.34 & 0.08 & -0.85 & -2.74 & -1.02 & -2.74 \\
\hline Kurt & -0.36 & -0.73 & .10 & -0.69 & -0.71 & -0.16 & -0.57 & 1.22 & 1.34 & -0.45 & -0.25 & -1.01 & -0.10 & 5.67 & -0.55 & 5.67 \\
\hline & $0.15 n$ & $0.18 n$ & $0.11 n$ & $0.21 \mathrm{Ln}$ & $0.26 \mathrm{Ln}$ & $0.11 n$ & $0.18 n$ & $0.21 \mathrm{Ln}$ & $0.23 \mathrm{Ln}$ & $0.12 n$ & $0.13 n$ & $0.15 n$ & $0.24 \mathrm{Ln}$ & $0.53 \mathrm{Ln}$ & $0.37 \mathrm{Ln}$ & $0.53 \mathrm{Ln}$ \\
\hline
\end{tabular}

SD - Standard deviation; CV - Coefficient of variation; Skew - Skewness; Kurt - Kurtosis; D - Maximum deviation

$\mathrm{n}$ - Normal frequency distribution, Ln - log- normal frequency distribution, according to a Kolmogorov-Smirnov test at $\mathrm{p} \leq 0.01$

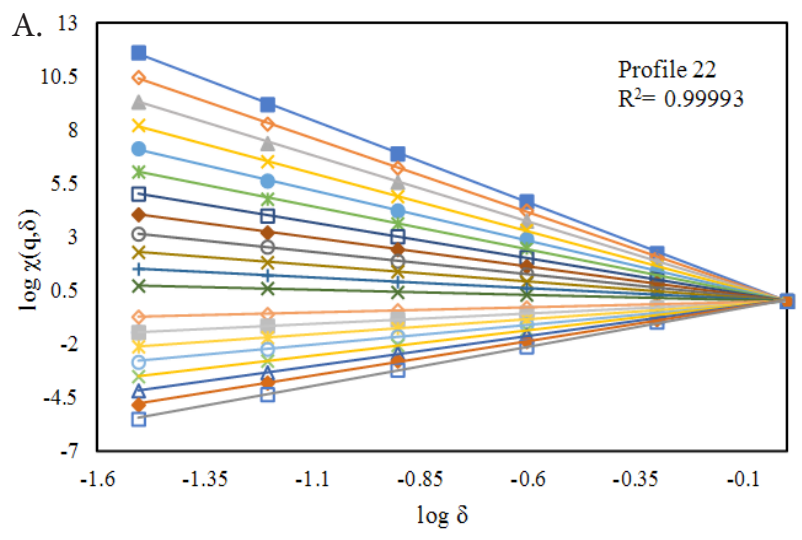

C.

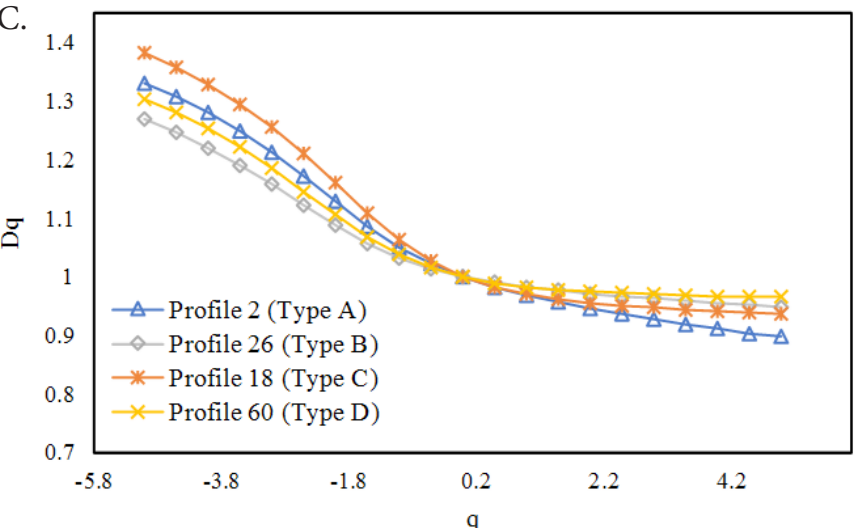

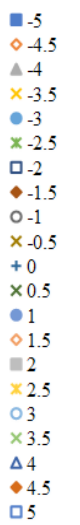
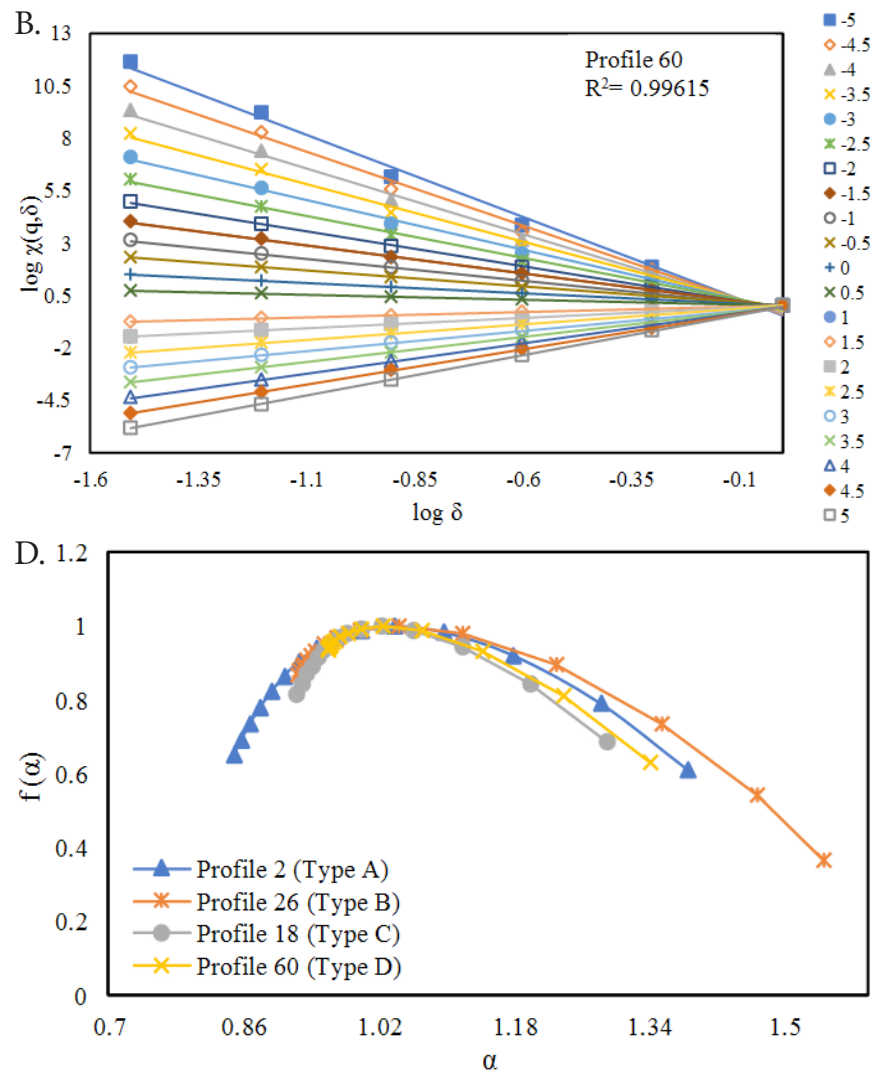

Where: $\chi(\mathrm{q}, \delta)$ - Partition function versus depth dependent resolution ( $\delta$ ); Dq - Generalized dimension versus the moments (q); D - Dimension for the moments $\mathrm{q}$; $\mathrm{q}$ - Moments ( $\mathrm{q}$ $=0 ; \mathrm{q}=1 \mathrm{e} q=2) ; \mathrm{f}(\alpha)$ - Spectrum of singularity and function of singularity strength $\alpha$

Figure 3. Log-log plots of the partition function for the graphs that presented the best (A) and worst (B) coefficient of determination $\left(R^{2}\right)$, generalized dimension - $D q(C)$ and the singularity spectrum - $f(\alpha)(D)$ of soil resistance to penetration data 
Table 2. Multifractal parameters obtained from the generalized dimension $\left(\mathrm{D}_{-5}-\mathrm{D}_{5}, \mathrm{D}_{-5}, \mathrm{D}_{5}, \mathrm{D}_{0}, \mathrm{D}_{1}\right.$ and $\left.\mathrm{D}_{2}\right)$ and the singularity $\operatorname{spectra}\left(q_{+}, q, a_{0}, a_{\max }\right.$ and $\left.\alpha_{\min }\right)$ for profile of penetration resistance (PR)

\begin{tabular}{|c|c|c|c|c|c|c|c|c|c|c|c|}
\hline Profile & $D_{-5}-D_{5}$ & $\overline{D_{-5}}$ & $\mathrm{D}_{5}$ & $\bar{D}_{0}$ & $\overline{D_{1}}$ & $\overline{D_{2}}$ & $q+$ & q- & $\alpha_{0}$ & $\alpha_{\max }$ & $\alpha_{\min }$ \\
\hline \multicolumn{12}{|c|}{ Type A } \\
\hline 2 & 0.432 & $0.897 \pm 0.019$ & $1.330 \pm 0.047$ & $1.000 \pm 0.000$ & $0.969 \pm 0.004$ & $0.946 \pm 0.009$ & 5.000 & -2.000 & $1.038 \pm 0.005$ & $1.386 \pm 0.075$ & $0.848 \pm 0.036$ \\
\hline 7 & 0.373 & $0.895 \pm 0.013$ & $1.268 \pm 0.032$ & $1.000 \pm 0.000$ & $0.964 \pm 0.004$ & $0.938 \pm 0.007$ & 5.000 & -3.000 & $1.042 \pm 0.005$ & $1.409 \pm 0.067$ & $0.855 \pm 0.024$ \\
\hline 10 & 0.417 & $0.894 \pm 0.016$ & $1.311 \pm 0.027$ & $1.000 \pm 0.000$ & $0.965 \pm 0.004$ & $0.941 \pm 0.008$ & 5.000 & -3.500 & $1.044 \pm 0.006$ & $1.507 \pm 0.054$ & $0.844 \pm 0.030$ \\
\hline 21 & 0.354 & $0.930 \pm 0.010$ & $1.284 \pm 0.012$ & $1.000 \pm 0.000$ & $0.972 \pm 0.003$ & $0.956 \pm 0.005$ & 5.000 & -4.500 & $1.036 \pm 0.004$ & $1.509 \pm 0.024$ & $0.906 \pm 0.020$ \\
\hline \multicolumn{12}{|c|}{ Type B } \\
\hline 11 & 0.424 & $0.923 \pm 0.012$ & $1.347 \pm 0.021$ & $1.000 \pm 0.000$ & $0.968 \pm 0.003$ & $0.950 \pm 0.006$ & 5.000 & -3.000 & $1.042 \pm 0.005$ & $1.542 \pm 0.021$ & $0.898 \pm 0.024$ \\
\hline 13 & 0.496 & $0.892 \pm 0.009$ & $1.388 \pm 0.038$ & $1.000 \pm 0.000$ & $0.965 \pm 0.003$ & $0.940 \pm 0.006$ & 5.000 & -2.000 & $1.045 \pm 0.005$ & $1.471 \pm 0.038$ & $0.842 \pm 0.016$ \\
\hline 16 & 0.491 & $0.866 \pm 0.013$ & $1.356 \pm 0.032$ & $1.000 \pm 0.000$ & $0.953 \pm 0.009$ & $0.920 \pm 0.018$ & 5.000 & -2.500 & $1.056 \pm 0.011$ & $1.492 \pm 0.032$ & $0.818 \pm 0.052$ \\
\hline 26 & 0.444 & $0.938 \pm 0.007$ & $1.381 \pm 0.032$ & $1.000 \pm 0.000$ & $0.970 \pm 0.002$ & $0.955 \pm 0.004$ & 5.000 & -2.500 & $1.043 \pm 0.004$ & $1.546 \pm 0.052$ & $0.924 \pm 0.011$ \\
\hline \multicolumn{12}{|c|}{ Type C } \\
\hline 18 & 0.319 & $0.949 \pm 0.006$ & $1.268 \pm 0.055$ & $1.000 \pm 0.000$ & $0.982 \pm 0.001$ & $0.971 \pm 0.002$ & 5.000 & -2.000 & $1.023 \pm 0.003$ & $1.289 \pm 0.078$ & $0.922 \pm 0.015$ \\
\hline 22 & 0.361 & $0.922 \pm 0.014$ & $1.283 \pm 0.007$ & $1.000 \pm 0.000$ & $0.973 \pm 0.004$ & $0.956 \pm 0.007$ & 5.000 & -5.000 & $1.034 \pm 0.005$ & $1.519 \pm 0.015$ & $0.885 \pm 0.027$ \\
\hline 25 & 0.404 & $0.931 \pm 0.011$ & $1.335 \pm 0.017$ & $1.000 \pm 0.000$ & $0.972 \pm 0.002$ & $0.956 \pm 0.005$ & 5.000 & -3.000 & $1.038 \pm 0.002$ & $1.527 \pm 0.039$ & $0.910 \pm 0.022$ \\
\hline 27 & 0.394 & $0.904 \pm 0.009$ & $1.298 \pm 0.040$ & $1.000 \pm 0.000$ & $0.964 \pm 0.001$ & $0.941 \pm 0.001$ & 5.000 & -2.500 & $1.044 \pm 0.003$ & $1.408 \pm 0.075$ & $0.874 \pm 0.023$ \\
\hline \multicolumn{12}{|c|}{ Type D } \\
\hline 28 & 0.359 & $0.944 \pm 0.009$ & $1.304 \pm 0.029$ & $1.000 \pm 0.000$ & $0.977 \pm 0.003$ & $0.963 \pm 0.005$ & 5.000 & -2.500 & $1.031 \pm 0.004$ & $1.427 \pm 0.058$ & $0.928 \pm 0.015$ \\
\hline 41 & 0.338 & 0.9650 .001 & $1.303 \pm 0.057$ & $1.000 \pm 0.000$ & $0.983 \pm 0.002$ & $0.974 \pm 0.002$ & 5.000 & -2.000 & $1.025 \pm 0.004$ & $1.342 \pm 0.089$ & $0.959 \pm 0.001$ \\
\hline 47 & 0.367 & $0.944 \pm 0.013$ & $1.311 \pm 0.030$ & $1.000 \pm 0.000$ & $0.973 \pm 0.003$ & $0.959 \pm 0.006$ & 5.000 & -3.000 & $1.037 \pm 0.004$ & $1.484 \pm 0.062$ & $0.933 \pm 0.025$ \\
\hline 60 & 0.338 & $0.965 \pm 0.001$ & $1.303 \pm 0.057$ & $1.000 \pm 0.000$ & $0.983 \pm 0.002$ & $0.974 \pm 0.002$ & 5.000 & -2.000 & $1.025 \pm 0.004$ & $1.342 \pm 0.089$ & $0.959 \pm 0.001$ \\
\hline
\end{tabular}

generalized dimensions varied between profiles (Figure 3C; Table 2) and showed greater heterogeneity of profile 2 in type $\mathrm{A}\left(\mathrm{D}_{-5}-\mathrm{D}_{5}=0.432\right)$, of profile 13 in type $\mathrm{B}\left(\mathrm{D}_{-5}-\mathrm{D}_{5}=0.496\right)$, of profile 25 in type $C\left(D_{-5}-D_{5}=0.404\right)$, and of profile 47 in type $\mathrm{D}\left(\mathrm{D}_{-5}-\mathrm{D}_{5}=0.367\right)$. The capacity dimension $\left(\mathrm{D}_{0}\right)$ was constant over all profiles in the four types $\left(D_{0}=1,000\right)$. The dimension $\mathrm{D}_{1}$ (or entropy dimension) showed the largest values in the profiles $21\left(\mathrm{D}_{1}=0.972 \pm 0.003\right), 26\left(\mathrm{D}_{1}=0.970 \pm 0.002\right), 18$ $\left(D_{1}=0.982 \pm 0.001\right), 41$ and $60\left(D_{1}=0.983 \pm 0.002\right)$ in types $\mathrm{A}, \mathrm{B}, \mathrm{C}$, and $\mathrm{D}$, respectively.

The variation in the dimension values $\mathrm{Dq}\left(\mathrm{D}_{-5-} \mathrm{D}_{5}\right)$ was used to determine the multifractality or heterogeneity of the data (Paz-Ferreiro et al., 2010; Dafonte et al., 2015; Wilson et al., 2015). In the present study, the vertical PR profiles (profiles 11 $\left[\mathrm{D}_{-5}-\mathrm{D}_{5}=0.424\right], 13\left[\mathrm{D}_{-5}-\mathrm{D}_{5}=0.496\right]$ and $\left.26\left[\mathrm{D}_{-5}-\mathrm{D}_{5}=0.444\right]\right)$ in the type $\mathrm{B}$ relief unit were more heterogeneous compared to the profiles of the relief unit types $\mathrm{A}, \mathrm{C}$, and $\mathrm{D}$ (Table 2). The multifractal description of $\mathrm{PR}$ data on the type $\mathrm{B}$ relief unit is important information, as this relief unit represents 3.27 ha (47.73\%) of the study area, thus this information can be used for the delimitation of specific management areas using multifractal parameters.

The values of $\alpha$ and $f(\alpha)$ for the singularity spectra of the four patterns were calculated for the moment $\mathrm{q}$, with $\mathrm{R}^{2}$ values above 0.90. For the four relief units (types A, B, C and D), $\mathrm{q}_{+}$was constant (-5) and q. ranged from -2 to -5 among the profiles (Table 2).

The singularity spectra for the PR profiles (types A, B, C and D) are shown in Figure 3D. The singularity spectra had a parabola shape with variation in the skewness of the branches. According to Dafonte et al. (2015), Paz-Ferreiro et al. (2018) and Siqueira et al. (2018), the skewness of spectra indicates the dominance of outliers in the data. High coefficients of variation were observed in the present study (Table 1). The singularity spectra were broad and stretched to the right for all analyzed profiles (Figure $3 \mathrm{D}$ ), albeit with small variations in type $\mathrm{D}$. The width and amplitude $\left(\alpha_{\max }-\alpha_{\min }\right)$ of the singularity spectra of PR profiles varied between the different relief units (Table 2).
Values of $\alpha_{\max }$ were higher in profile $21\left(\alpha_{\max }=1.509\right.$, type A), profile $26\left(\alpha_{\max }=1,546\right.$, type $\left.B\right)$, profile $25\left(\alpha_{\max }=1,527\right.$, type $C)$, and profile $47\left(\alpha_{\max }=1.484\right.$, type $\left.D\right)$. For the values of $\alpha_{\text {min }}$, the lowest values were observed in profiles $10\left(\alpha_{\text {mim }}=\right.$ 0.844 , type A), 16 ( $\alpha_{\text {mim }}=0.818$, type B), $27\left(\alpha_{\text {mim }}=0.874\right.$, type C) and $28\left(\alpha_{\text {mim }}=0.928\right.$, type D). Variations in the width $\left(\alpha_{\text {min }}\right)$ and range $\left(\alpha_{\max }\right)$ of singularity spectra indicate heterogeneity (Table 2), as these parameters provide information on the variability in the measured scales (Vidal-Vázquez et al., 2010, 2013; Wilson et al., 2016; Paz-Ferreiro et al., 2018). Width of the $f(\alpha)$ - $\alpha$ spectrum is positively correlated with heterogeneity in the local scaling indices (Siqueira et al., 2018).

Spatial distribution maps and models of the semivariogram for the mean and maximum PR at 0-0.60 m depth, the parameters $\mathrm{PR}_{\mathrm{D}-5-\mathrm{D} 5}, \mathrm{PR}_{\alpha 0-\alpha 5}$ and the Hurst exponent $(\mathrm{H})$ produced by ordinary kriging are shown in Figure 4 . The best fit to the data set was observed in the exponential model (Figure 4), apart from $\mathrm{PR}_{\text {maximum }}$ that was adjusted to the Gaussian model, which may be explained by its range value $(\mathrm{a}=32 \mathrm{~m})$. This was below $\mathrm{PR}_{\text {mean }}(\mathrm{a}=38.7 \mathrm{~m})$, indicating that $\mathrm{PR}_{\text {maximum }}$ values were more heterogeneous in the study area, whereas $\mathrm{PR}_{\text {mean }}$ values varied on a smaller scale in the study area. The parameters $\mathrm{PR} \mathrm{D}_{-5-\mathrm{D} 5}, \mathrm{PR}_{\alpha 0-\alpha 5}$, and $\mathrm{H}$ showed range values of $41,31.7$, and $41 \mathrm{~m}$, respectively.

The spatial maps for the mean and maximum PR suggest an inverse relationship between the parameters $\mathrm{PR}_{\mathrm{D}-5-\mathrm{D} 5}$ and $\mathrm{PR}_{\alpha 0-\alpha 5}$. In this sense, linear correlations were calculated for all parameters involved in spatial analysis in order to confirm the spatial pattern of the contour lines. Positive correlations of $\mathrm{PR}_{\text {mean }}$ and $\mathrm{PR}_{\text {maximun }}(|\mathrm{r}|=0.565), \mathrm{PR}_{\mathrm{D}-5-\mathrm{D} 5}$ and $\mathrm{PR}_{\alpha 0-\alpha 5}(|\mathrm{r}|=$ $0.486)$, and of $P R_{\text {maximun }}$ and $P R_{\alpha 0-\alpha 5}(|r|=0.333)$ were observed. Negative correlations were observed in $\mathrm{PR}_{\mathrm{D}-5-\mathrm{D} 5}$ and $\mathrm{H}(|\mathrm{r}|=$ -0.498), $\mathrm{PR}_{\alpha 0-\alpha 5}$ and $\mathrm{H}(|\mathrm{r}|=-0.183)$, and in $\mathrm{PR}_{\text {mean }}$ and $\mathrm{H}(|\mathrm{r}|$ $=-0.102)$. The negative correlations of $\mathrm{H}$ and $\mathrm{PR}_{\text {mean }}$ observed in the present study corroborate the results of Siqueira et al. (2013) who examined the multifractality of vertical profiles of $\mathrm{PR}$ and found a negative correlation of $\mathrm{H}$ and $\mathrm{PR}_{\text {mean }}(|\mathrm{r}|$ $=-0.316)$. 


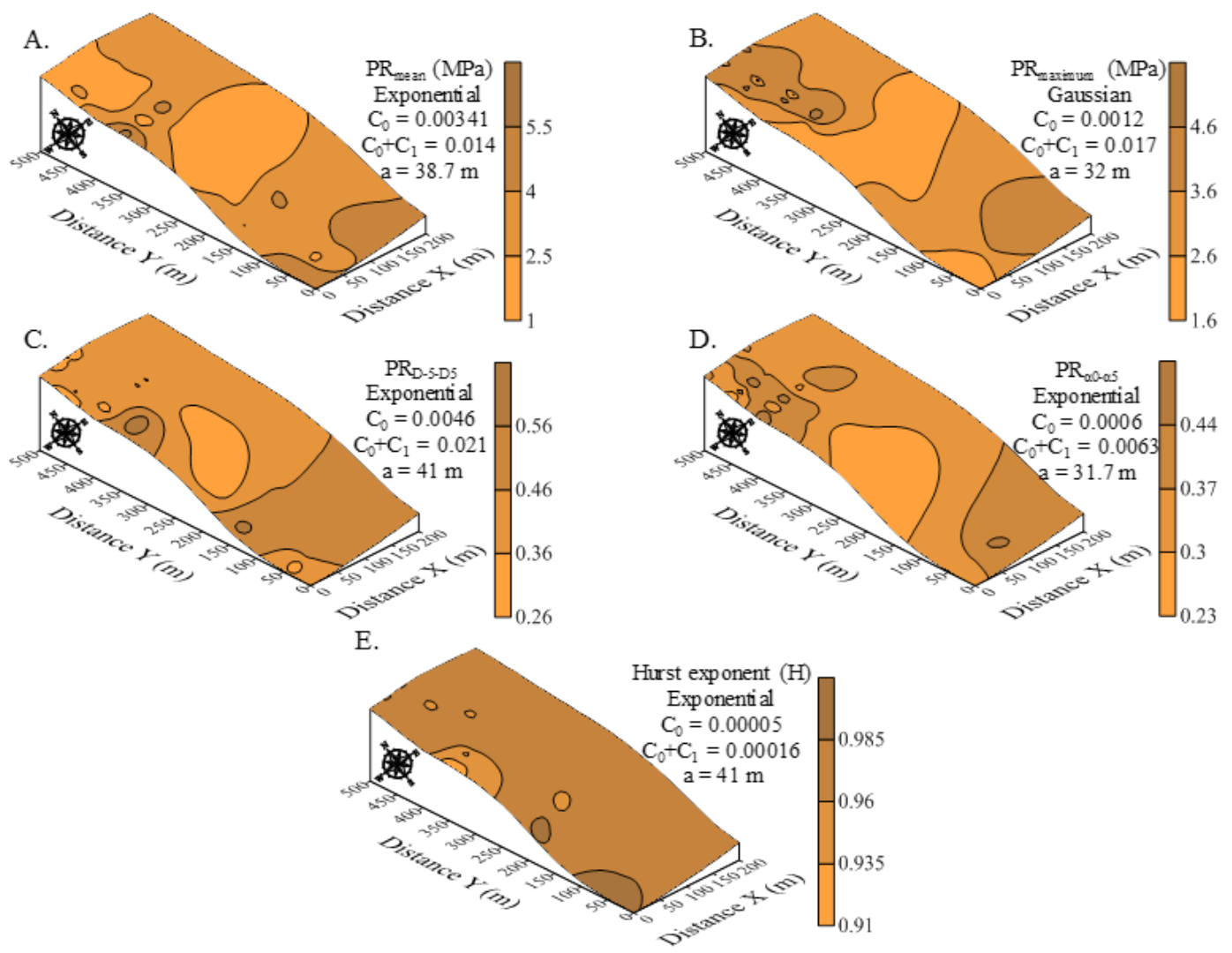

Figure 4. Spatial maps for the mean (A) and maximum $P R(B)$ at depth of 0-0.6 $\mathrm{m}$, and for the parameters $\mathrm{PR}_{\mathrm{D}-5-\mathrm{D} 5}[\mathrm{difference}$ between the minimum dimension $\left(\mathrm{D}_{-5}\right)$ and maximum dimension $\left.\left(\mathrm{D}_{5}\right)\right](\mathrm{C}), \mathrm{PR}_{\alpha 0-\alpha 5}$ (difference between the Hölder exponent in the momment 0 and 5) (D), and Hurst exponent (H) (E)

The maps of spatial variability for mean and maximum $P R$ at depths of 0-0.60 m (Figures $4 \mathrm{~A}$ and $\mathrm{B}$ ) showed a pattern of distribution of contour lines similar to that of the topographic map (Figure 1), which may explain higher averages and higher variability in the type B relief unit (Table 1), compared with the other relief units. As mentioned above, the type $\mathrm{B}$ relief unit showed the highest multifractality of the data (Figure 3C; Table 2) and the highest values of $\mathrm{Dq}\left(\mathrm{D}_{-5}-\mathrm{D}_{5}\right)$. This suggests that management zones can be delimited based on relief units. The spatial variability map of $\mathrm{PR}_{\mathrm{D}-5-\mathrm{D} 5}$ (Figure $4 \mathrm{C}$ ) thus allows the distinction of two management zones, one in the upper part of the area comprising types $\mathrm{A}$ and $\mathrm{B}$, and the other in the lower part including types $\mathrm{C}$ and $\mathrm{D}$.

The map of $\mathrm{PR}_{\alpha 0-\alpha 5}$ (Figure $4 \mathrm{D}$ ) facilitates the delimitation of two specific management zones, following the same pattern observed in the $\mathrm{PR}_{\mathrm{D}-5-\mathrm{D} 5}$ map (Figure $4 \mathrm{C}$ ), with two specific management zones, which mainly follow the contour in the $\mathrm{PR}_{\text {maximum }}$ map (Figure 4B). This is in line with the results of Siqueira et al. (2013) who assessed multifractality of vertical PR profiles and observed the same pattern of distribution. The relation of the spatial variability maps of $\mathrm{PR}_{\text {maximum }}$ and $\mathrm{PR}_{\mathrm{a} 0-\mathrm{a} 5}$ (Figures $4 \mathrm{~B}$ and $\mathrm{D}$ ) confirms the values of the observed positive linear correlation of these parameters $(|\mathrm{r}|=0.333)$. Using the $\mathrm{PR}_{\text {maximum }}$ modeled by means of geostatistical tools and multifractal analysis allows inferences on the state of soil compaction. In this sense, it is verified that most of the study

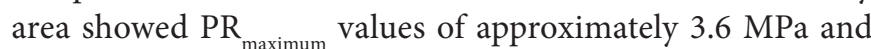
showed no problems due to soil compaction, which is in line with the studies of Lipiec \& Hatano (2003), Vaz et al. (2011), Sá et al. (2016), Lima et al. (2017) and Tavares et al. (2017).
The spatial pattern of $\mathrm{H}$ in the study area was above 0.91 (Figure 4E). The values of $\mathrm{H}$ describe the persistence or anti-persistence of a series following a law of scale. Thus, the spatial variability map of $\mathrm{H}$ indicates the multifractality and non-randomness of the vertical PR profiles, suggesting that independent of the relief unit the PR measured in the $0-0.60 \mathrm{~m}$ depth layer is autocorrelated.

\section{Conclusions}

1. The vertical profiles of $P R$ in the 0-0.6 m depth layer at $0.01 \mathrm{~m}$ intervals was multifractal as indicated by the singularity spectrum ( $\alpha$ ) versus $f(\alpha)$ and by the generalized dimension (Dq).

2. The vertical PR profiles in the type B relief unit showed greater heterogeneity in the $\mathrm{Dq}\left(\mathrm{D}_{-5}-\mathrm{D}_{5}\right)$ dimension compared to the other relief units (types A, C and D), demonstrating greater multifractality of the PR series.

3. The use of geostatistics and multifractal analysis allowed the identification of zones for homogeneous management of $\mathrm{PR}$, considering variation in the relief. $\mathrm{PR}_{\text {maximum }}$ and $\mathrm{PR}_{\mathrm{D}-5-\mathrm{D} 5}$ allowed the delimitation of two management zones.

\section{ACKnowledgments}

The authors acknowledge the Fundação de Amparo à Pesquisa e ao Desenvolvimento Científico e Tecnológico do Maranhão (FAPEMA - UNIVERSAL-001160/17 and BD02105/17). This study was financed in part by the Coordenação de Aperfeiçoamento de Pessoal de Nível Superior - Brasil (CAPES, Brazil) - Finance Code 001". We extend our gratitude to the 
Conselho Nacional de Desenvolvimento Científico e Tecnológico (CNPq, Brazil - Process 429354/2016-9, 307619/2016-8 and 103961/2018-6).

\section{Literature Cited}

Banerjee, S.; He, Y.; Guo, X.; Si, B. C. Spatial relationships between leaf area index and topographic factors in a semiarid grassland: Joint multifractal analysis. Australian Journal of Crop Science, v.5, p.756-763, 2011.

Caniego, F. J.; Ibáñez, J. J.; Martínez, F. S. J. Selfsimilarity of pedotaxa distributions at the planetary scale: A multifractal approach. Geoderma, v.134, p.306-317, 2006. https://doi.org/10.1016/j. geoderma.2006.03.007

Chhabra, A.; Jensen, R. V. Direct determination of the $f(\alpha)$ singularity spectrum. Physical Review Letters, v.62, p.1327-1330, 1989. https://doi.org/10.1103/PhysRevLett.62.1327

Dafonte, J. D.; Valcárcel-Armesto, M.; Dias, R. da S.; Vidal-Vázquez, E.; Paz-González, A. Assessment of the spatial variability of soil chemical properties along a transect using multifractal analysis. Cadernos do Laboratório Xeolóxico de Laxe, v.38, p.11-24, 2015.

Evertsz, C. J. G.; Mandelbrot, B. B. Self-similarity of harmonic measure on DLA. Physica A: Statistical Mechanics and its Applications, v.185, p.77-86, 1992. https://doi.org/10.1016/0378-4371(92)90440-2

Folorunso, O. A.; Puente, C. E.; Rolston, D. E.; Pinzon, J. E. Statistical and fractal evaluation of the spatial characteristics of soil surface strength. Soil Science Society of America Journal, v.58, p.284-294, 1994. https://doi.org/10.2136/sssaj1994.03615995005800020004x

Golden Software. Surfer version 11 - Surface mapping system. Colorado: Golden Software, 2014. CD-Rom.

Gonçalves, W. G.; Severiano, E. da C.; Silva, F. G.; Costa, K. A. de P.; Guimarães Junnyor, W. S.; Melo, G. B. Least limiting water range in assessing compaction in a Brazilian Cerrado Latosol growing sugarcane. Revista Brasileira de Ciência do Solo, v.38, p.432-443, 2014. https://doi.org/10.1590/S0100-06832014000200008

Halsey, T. C.; Jensen, M. H.; Kadanoff, L. P.; Procaccia, I.; Shraiman, B. I. Fractal measures and their singularities: The characterization of strange sets. Physics Nuclear, v.33, p.1141-1151, 1986. https:// doi.org/10.1103/PhysRevA.33.1141

Lima, R. P. de; Silva, A. P. da; Giarola, N. F. B.; Silva, A. R. da; Rolim, M. M. Changes in soil compaction indicators in response to agricultural field traffic. Biosystems Engineering, v.162, p.1-10, 2017. https://doi.org/10.1016/j.biosystemseng.2017.07.002

Lipiec, J.; Hatano, R. Quantification of compaction effects on soil physical properties and crop growth. Geoderma, v.116, p.107-136, 2003. https://doi.org/10.1016/S0016-7061(03)00097-1

Otto, R.; Silva, A. P. da; Franco, H. C. J.; Oliveira, E. C. A. de; Trivelin, P. C. O. High soil penetration resistance reduces sugarcane root system development. Soil \& Tillage Research, v.117, p.201-210, 2011. https://doi.org/10.1016/j.still.2011.10.005

Paz-Ferreiro, J.; Marinho, M. de A.; Abreu, C. A. de; VidalVázquez, E. Soil texture effects on multifractal behaviour of nitrogen adsorption and desorption isotherms. Biosystems Engineering, v.168, p.121-132, 2018. https://doi.org/10.1016/j. biosystemseng.2018.01.009

Paz-Ferreiro, J.; Marinho, M. de A.; Silva, L. F. S. da; Motoshima, S. T.; Dias, R. da S. The effects of bulk density and water potential on multifractal characteristics of soil penetration resistance microprofiles measured on disturbed soil samples. Vadose Zone Journal, v.12, p.1-13, 2013. https://doi.org/10.2136/vzj2012.0185
Paz-Ferreiro, J.; Miranda, J. G. V.; Vidal-Vázquez, E. Multifractal analysis of soil porosity based on mercury injection and nitrogen adsorption. Vadose Zone Journal, v.9, p.325-335, 2010. https:// doi.org/10.2136/vzj2009.0090

R Development Core Team. R: A language and environment for statistical computing. Vienna: R Foundation for Statistical Computing, 2017. sp.

Roisin, C. J. A multifractal approach for assessing the structural state of tilled soils. Soil Science Society of America Journal, v.71, p.1525, 2007. https://doi.org/10.2136/sssaj2006.0132

Sá, M. A. C. de; Santos Junior, J. de D. G. dos; Franz, C. A. B.; Rein, T. A. Qualidade física do solo e produtividade da cana-de-açúcar com uso da escarificação entre linhas de plantio. Pesquisa Agropecuária Brasileira, v.51, p.1610-1622, 2016. https://doi.org/10.1590/s0100204x2016000900061

Siqueira, G. M.; Silva, Ê. F. de F. e; Montenegro, A. A. A. de; VidalVázquez, E.; Paz-Ferreiro, J. Multifractal analysis of vertical profiles of soil penetration resistance at the field scale. Nonlinear Processes in Geophysics, v.20, p.529-541, 2013. https://doi. org/10.5194/npg-20-529-2013

Siqueira, G. M.; Silva, Ê. F. de F. e; Vidal-Vázquez, E.; Paz-González, A. Multifractal and joint multifractal analysis of general soil properties and altitude along a transect. Biosystems Engineering, v.168, p.105-120, 2018. https://doi.org/10.1016/j. biosystemseng.2017.08.024

Siqueira, G. M.; Silva, J. S. da; Bezerra, J. M.; Silva, Ê. F. de F. e; Dafonte, J. D.; Melo, R. F. de. Estacionariedade do conteúdo de água de um Espodossolo Humilúvico. Revista Brasileira de Engenharia Agrícola e Ambiental, v.19, p.439-448, 2015. https:// doi.org/10.1590/1807-1929/agriambi.v19n5p439-448

Souza, G. S. de; Souza, Z. M. de; Cooper, M.; Tormena, C. A. Controlled traffic and soil physical quality of an Oxisol under sugarcane cultivation. Scientia Agricola, v.72, p.270-277, 2015. https://doi.org/10.1590/0103-9016-2014-0078

Tavares, U. E.; Rolim, M. M.; Simões Neto, D. E.; Pedrosa, E. M. R.; Magalhães, A. G.; Silva, Ê. F. de F. e. Aggregate stability and penetration resistance after mobilization of a dystrocohesive Ultisol. Revista Brasileira de Engenharia Agrícola e Ambiental, v.21, p.752-757, 2017. https://doi.org/10.1590/1807-1929/agriambi.v21n11p752-757

Vaz, C. M. P.; Manieri, J. M.; Maria, I. C. de; Tuller, M. Modeling and correction of soil penetration resistance for varying soil water content. Geoderma, v.166, p.92-101, 2011. https://doi. org/10.1016/j.geoderma.2011.07.016

Vepraskas, M. J.; Miner, G. S. Effects of subsoiling and mechanical impedance on tobacco root growth. Soil Science Society of America Journal, v.50, p.423-427, 1986. https://doi.org/10.2136/ sssaj1986.03615995005000020034x

Vidal-Vázquez, E.; Bertol, I.; Siqueira, G. M.; Paz-Ferreiro, J.; Dafonte, J. D. Evolution of the soil surface roughness using geostatistical analysis. Bragantia, v.69, p.141-152, 2010. https://doi.org/10.1590/ S0006-87052010000500015

Vidal-Vázquez, E.; Camargo, O. A. de; Vieira, S. R.; Miranda, J. G. V.; Menk, J. R. F.; Siqueira, G. M.; Mirás-Avalos, J. M.; Paz-González, A. Multifractal analysis of soil properties along two perpendicular transects. Vadose Zone Journal, v.12, p.1-13, 2013. https://doi. org/10.2136/vzj2012.0188

Wilson, M. G.; Mirás-Avalos, J. M.; Lado, M.; Paz-González, A. Multifractal analysis of vertical profiles of soil penetration resistance at varying water contents. Vadose Zone Journal, v.15, p.1-10, 2016. https://doi.org/10.2136/vzj2015.04.0063 